\title{
Meningkatkan Kemampuan Siswa Memahami Isi Teks melalui Implementasi Model Pembelajaran Problem Based Learning
}

\author{
Made Sukiasih* \\ Sekolah Menengah Pertama Negeri 2 Singaraja, Bali, Indonesia
}

A R T I C L E I N F O

Article history:

Received 10 Maret 2018

Received in revised

form 20 Maret 2018

Accepted 12 April

2018

Available online 20

Mei 2018

Kata Kunci:

model problem

based learning,

kemampuan

memahami isi teks

Keywords:

problem based

learning model,

ability to understand

text content
A B S T R A K

Penelitian ini dilaksanakan di Kelas IX-4 SMP Negeri 2 Singaraja pada semester ganjil tahun pelajaran 2016/2017, dengan kondisi ratarata kemampuan siswa dalam memahami isi teks hanya 71,11 . Prosentase ketercapaian KKM baru mencapai 29,73\%. Tujuan penelitian tindakan kelas ini adalah untuk meningkatkan kemampuan siswa dalam memahami isi teks melalui implementasi Model Pembelajaran Problem Based Learning. Subjek penelitian ini adalah semua siswa kelas IX-4 SMP Negeri 2 Singaraja yang berjumlah 37 orang siswa, dengan jumlah laki-laki 18 orang dan 19 orang perempuan. Metode yang digunakan pengumpulan datanya melalui tes uraian, yang selanjutnya dianalisis dengan menggunakan metode deskriptif kuantitatif. Data disajikan dalam bentuk rata-rata prestasi belajar dan prosentase ketuntasan belajar. Hasil yang diperoleh dari penelitian ini adalah adanya perkembangan kemampuan siswa dalam memahami isi teks yang sangat positif. Pada awalnya rata-rata kemampuan siswa dalam memahami isi teks hanya; 71,11 dengan ketuntasan belajar hanya; 29,73\%, selanjutnya setelah pelaksanaan siklus I meningkat menjadi rata-rata; 75,35 dengan ketuntasan belajar mencapai 54,05\%. Dari Siklus I ke Siklus II terjadi juga peningkatan yakni mencapai rata-rata 79,19 dan ketuntasan belajar $89,19 \%$. Kesimpulan yang diperoleh dari penelitian ini adalah implementasi model pembelajaran Problem Based Learning dapat meningkatkan kemampuan siswa kelas IX-4 SMP Negeri 2 Singaraja dalam memahami isi teks pada smester ganjil tahun pelajaran 2016/2017.

\section{A B S T R A C T}

This research was conducted in Class IX-4 SMP Negeri 2 Singaraja in odd semester, year $2016 / 2017$, with the average condition of the students' ability in understanding the contents of the text only 71.11. This condition has not met the KKM. Percentage of new KKM achievement reached $29.73 \%$. The purpose of this classroom action research is to improve students' ability in understanding the text content through the implementation of Problem Based Learning Model Learning. The method used to collect data through the test description (the ability of students in understanding the contents of the text), which then analyzed by using descriptive method quantitative. The data are presented in the form of average learning achievement and learning mastery procession. The results obtained from this research is the development of students' ability in understanding the text content was very positive. At first the average ability of students in understanding the content of the text only; 71,11 with complete learning only; $29.73 \%$, then after the implementation of Cycle I increased to average, 75.35 with learning completeness reached $54.05 \%$ From Cycle I to Cycle II also increased the average that reached 79.19 and learning mastery $89.19 \%$. The conclusion obtained from this research is Implementation of Problem Based Learning Model can improve the ability of students of class IX-4 SMP Negeri 2 Singaraja in understanding the text content in odd semester at 2016/2017. 



\section{Pendahuluan}

Membaca merupakan kegiatan yang tidak hanya melafalkan simbol tulisan, tetapi juga memahami isi dari bacaan. Dalam pembelajaran membaca, guru seharusnya menerapkan teknik yang tepat agar tujuan membaca tercapai. Kenyataannya, guru belum menerapkan teknik pembelajaran yang tepat sehingga mempengaruhi kemampuan siswa memahami isi bacaan. Dengan demikian perlu tindakan untuk meningkatkan kemampuan siswa memahami isi bacaan. Memahami bacaan suatu teks itu penting, terkait dengan fungsi utama bahasa. Fungsi utama bahasa adalah sebagai sarana komunikasi. Bahasa digunakan sebagai alat berkomunikasi antar penutur untuk berbagai keperluan dan situasi pemakaian. Dengan demikian maka, orang tidak akan berpikir tentang sistem bahasa, tetapi berpikir bagaimana menggunakan bahasa secara tepat sesuai dengan konteks dan situasi (depdiknas 2007:1). Konsekwensi dari pandangan tersebut adalah bahwa dalam pembelajaran bahasa haruslah lebih menekankan pada fungsi bahasa sebagai alat komunikasi. Artinya, pembelajaran bahasa Indonesia hendaknya diarahkan kepada upaya peningkatan kemampuan peserta didik agar mampu berkomunikasi dengan bahasa Indonesia yang baik dan benar secara lisan maupun secara tertulis. Mengingat bahwa komponen pengajaran bahasa Indonesia khususnya pada komponen pemahaman dan penggunaan, meliputi pemahaman dan penggunaan terkait dengan bidang sastra dan nonsastra, maka kemampuan siswa berkomunikasi dengan menggunakan bahasa Indonesia hendaklah juga ditumbuhkan pada bidang nonsastra dan sastra, sekaligus menumbuhkan apresiasi siswa terhadap karya sastra. Dalam pengajaran bahasa, aspek kebahasaan dan keterampilan berbahasa meliputi menyimak, berbicara, membaca, dan menulis harus disajikan secara terpadu. Keterampilan berkomunikasi secara lisan merupakan keterampilan mengemukakan buah pikiran dengan berbicara secara sistematis dan menarik. Udiyani (2017) menyatakan menulis merupakan suatu keterampilan berbahasa yang produktif karena akan menghasilkan suatu produk yaitu tulisan. Melalui menulis seseorang akan menjadi lebih kreatif dan kritis. Juliantari (2017) agar seseorang mudah melakukan analisis wacana, mereka harus mempunyai paradigma atau pandangan mengenai analisis wacana tersebut. Pemahaman mengenai paradigma adalah hal yang sangat fundamental.

Secara umum pembelajaran bahasa indonesia pada kelas memperlihatkan bahwa prestasi belajar tergolong rendah dan belum mencapai Kriteria Ketuntasan Minimal (KKM). Fakta yang mendukung kondisi kenyataan tersebut, adalah hasil tes awal yang dilakukan guru terhadap kemampuan siswa menceritakan kembali isi cerpen secara lisan di kelas IX-4 SMP Negeri 2 Singaraja, bahwa dari 37 siswa yang dites hanya terdapat 14 orang yang tuntas, sedangkan yang lainnya sebanyak 23 orang belum tuntas. Hal ini diakibatkan oleh karena pembelajaran bahasa indonesia yang dilaksanakan oleh guru masih konvensional, yakni pembelajaran masih berpusat pada guru dan belum berpusat pada siswa. Metode mengajar yang diterapkan oleh guru, lebih banyak menggunakan metode ceramah dan penugasan tanpa memanfaatkan model-model pembelajaran yang lebih menarik dan mampu menumbuhkan aktivitas siswa. Akibatnya, kualitas pembelajaran sangat rendah.

Dilihat dari pendidik, sekolah ini memiliki pendidik dengan rata-rata hampir seluruhnya berijazah S1- D4 seperti dipersyaratkan dalam standar nasional pendidikan, juga linieritas antara ijazah yang dimiliki dengan tugas-tugas yang dibebankan kepadanya sangat sessuai. Pengalaman mengajar guru juga rata-rata lebih dari 10 tahun menjadi guru sehingga dari sisi pengalaman mengajar guru cukup berpengalaman.

Namun demikian, ternyata prestasi belajar siswa khususnya dalam pembelajaran Bahasa Indonesia ternyata belum sesuai dengan harapan. Rendahnya prestasi belajar terlihat baru mencapai rata-rata hanya 70,81 dengan ketuntasan belajar 32,43\%. Kondisi tersebut disebabkan oleh strategi pembelajaran yang masih konvensional dengan dominasi guru yang sangat tinggi, sehingga peserta didik memperoleh pengetahuan dengan menunggu pemberian dari guru, dan sumber belajar satu-satunya juga berasal dari guru. Akibatnya penguasaan siswa terhadap pengetahuan dan keterampilan terkait dengan mata pelajaran yang harus dipelajari sangat dangkal dan terbatas, lebih-lebih mata pelajaran Bahasa Indonesia adalah merupakan salah satu mata pelajaran yang di UN kan, yang menuntut penguasaan pengetahuan dan keterampilan yang luas, sehingga siswa memiliki bekal yang cukup dalam menghadapi UN. Untuk itulah maka perlu dilaksanakan perubahan dalam strategi pembelajaran yang lebih menonjolkan aktivitas siswa, sehingga pembelajaran berbasis pada siswa. Langkah ini diimplementasikan dengan melakukan Penelitian Tindakan dengan memanfaatkan strategi pembelajaran Problem Based Learning. Langkah penelitian tindakan disesuaikan dengan tahapan-tahapan seperti; perencanaan, pelaksanaan, observasi, dan refleksi.

Seharusnya guru mampu menerapkan model pembelajaran yang dapat memancing dan menumbuhkan keaktivan siswa sehingga pembelajaran menjadi berpusat pada siswa. Penanggulangan permasalahan berkaitan dengan kondisi riil pembelajaran bahasa indonesia, sebagai upaya meningkatkan prestasi belajar siswa, maka penerapan model pembelajaran kooperatif dengan tipe Problem Based 
Learning (PBL). Model pembelajaran PBL merupakan model pembelajaran yang mengharapkan siswa mengerjakan permasalahan yang autentik dengan maksud untuk menyusun pengetahuan mereka sendiri, mengembangkan inkuiri, dan keterampilan berpikir lebih tinggi, mengembangkan kemandirian, dan percaya diri (Sudiatmika, 2016). Kurniawati (2013) berpendapat bahwa Kelebihan dari PBL yaitu siswa sangat antusias dan mempunyai perspektif yang luas tentang pemecahan masalah polusi, termasuk di dalamnya proses kreatif solusi alternatif. Natalia (2017) mengatakan bahwa media video dinyatakan tepat untuk meningkatkan keterampilan menulis teks eksposisi berpadu dengan model pembelajaran PBL karena video memiliki keunggulan dibandingkan media lain. Media video mampu memperjelas sajian ide dan mengilustrasikannya sehingga siswa tidak cepat lupa. Wibawa (2014) model PBL dan model siklus belajar 7E memberikan pengalaman yang berbeda dalam aktivitas belajar mahasiswa. PBL memiliki beberapa keunggulan, menurut Sanjaya (2009) keunggulanya yaitu 1) menantang kemampuan mahasiswa serta memberi kepuasan untuk menemukan pengetahuan baru bagi mahasiswa, 2) meningkatkan aktivitas pembelajaran mahasiswa, 3) membantu mahasiswa bagaimana mentransfer pengetahuan mahasiswa untuk memahami masalah dalam kehidupan nyata, 4) merangsang perkembangan kemajuan berpikir mahasiswa untuk menyelesaikan masalah yang dihadapi secara tepat (Widiana, 2014). Melalui PBL siswa memperoleh pengalaman dalam menangani masalah-masalah yang realistis, dan menekanan pada penggunaan komunikasi, kerjasama, dan sumber-sumber yang ada untuk merumuskan ide dan mengembangkan keterampilan penalaran (Nafiah 2012). PBL merupakan model pembelajaran inovatif yang dapat memberikan kondisi belajar aktif kepada siswa. Dimana siswa dapat secara aktif berfikir dalam menyelesaikan masalah yang berkaitan dengan kehidupan sosial mereka (Dewi, 2013).

Model pembelajaran PBL disetting memiliki bentuk yang diawali dengan sebuah masalah dimana instruktur sebagai pelatih, diakhiri penyajian dan kerja siswa, guru lebih sebagai pembimbing dan fasilitator, siswa diupayakan berpikir untuk memecahkan masalahnya sendiri. Pemusatan masalah disekitar materi pelajaran, kemampuan siswa mewujudkan hipotesis, kemampuan menyajikan hasil karya, menuntuk kemampuan menganalisis, mempresentasikan hasil, pengembangan kreativitas berpikir, menuntut kemampuan menyampaikan konsep-konsep terkait materi. Model ini menuntut kemampuan guru sebagai motivator dan fasilitator, kemampuan mengajar kelompok kecil, guru merupakan kunci keberhasilan pembelajaran, kelompok bisa lebih banyak 5-8 orang. Unit-unit pelajaran ditukar untuk setiap anggota kelompok. Guru harus menghindari ceramah, masalah disampaikan sebagai stimulus sehingga pembelajaran menantang, kemampuan metakognisi (mengolah data), siswa diupayakan memiliki kemampuan lebih dari menggali semua masalah yang ada dan kemampuan membandingkan temuan-temuannya dengan temua orang lain, sehingga siswa menjadi sangat aktif dalam mengikuti proses pembelajaran. Model ini menuntut kegiatan intelektual metode belajar sendiri, memproses apa yang mereka telah dapatkan dalam pikirannya untuk menjadi sesuatu yang bermakna. Mereka diupayakan untuk lebih produktif, mampu membuat analisa membiasakan mereka brpikir kritis, dapat mempresentasikan apa yang telah dipelajari. Model ini juga bisa diupayakan untuk pengembangan kemampuan akademik, menghindarkan siswa belajar dengan hapalan, dapat memberikan tambahan kemampuan untuk dapat mengasimilasikan dan mengakomodasikan informasi, serta menuntut kemampuan pemecahan dengan latihan khusus untuk mempertinggi daya ingat dengan berlatih untuk dapat memecahkan masalah-masalah yang ada.

Berdasarkan alasan itulah, maka permasalahan rendahnya kualitas pembelajaran bahasa indonesia yang sedang dihadapi khususnya kemampuan memahami isi teks, ditanggulangi dengan implementasi model pembelajaran PBL. Secara teoritis, hasil penelitian ini diharapkan akan bermanfaat; Bagi siswa, penelitian ini bermanfaat untuk meningkatkan kemampuan siswa dalam memahami isi teks, sehingga KKM dapat tercapai. Bagi Guru mata pelajaran Bahasa Indonesia, bernmanfaat untuk dapat meningkatkan profesionalitas dalam pembelajaran dengan memahai penanggulangan permasalahan dalam pembelajaran. Bagi sekolah, memperkaya model dan strategi pembelajaran dalam praktiknya untuk meningkatkan kualitas output sekolah.

\section{Metode}

Penelitian yang dilakukan termasuk penelitian tindakan kelas (PTK). Subjek penelitian ini adalah semua siswa kelas IX-4 SMP Negeri 2 Singaraja yang berjumlah 37 orang siswa, dengan jumlah laki-laki 18 orang dan 19 orang perempuan. Yang menjadi objek penelitian ini adalah kemampuan siswa dalam memahami isi teks, siswa kelas IX-4 SMP Negeri 2 Singaraja setelah diterapkan model pembelajaran PBL dalam proses pembelajaran. Penelitian ini dilakukan dari bulan Agustus sampai bulan Desember tahun 2016. 
Untuk mengumpulkan data penelitian ini digunakan tes uraian yang berjumlah 15 soal. Validasi instrument tes melalui 2 pakar di bidang Bahasa melalui musyawarah guru kelas. Metode yang digunakan untuk menganalisis data hasil penelitian ini adalah metode deskriptif baik untuk data kualitatif maupun untuk data kuantitatif. Kemudaian dianalisis dengan mencari mean, median, modus, standar deviasi, membuat interval kelas dan melakukan penyajian dalam bentuk tabel dan grafik. Dalam penelitian ini diusulkan tingkat keberhasilan yaitu untuk keterampilan berbicara siswa diharapkan pada siklus I maupun siklus II mencapai nilai rata-rata sesuai KKM (75) dan telah mencapai ketuntasan belajar klasikal mencapai 85.

\section{Hasil dan Pembahasan}

\section{Hasil}

Subjek penelitian ini di kelas IX-4 SMP Negeri 2 Singaraja, dengan posisi lingkungan sekolah sangat kondusif untuk proses pembelajaran, juga sarana dan prasarana penunjang pembelajaran sangat lengkat. Setelah memahami permasalahan yang terjadi, maka dilaksanakan tahapan perencanaan seperti; Merencanakan langkah-langkah menanggulangi permasalahan yang sedang dihadapi. Menyiapkan administrasi pendukung proses pembelajaran berupa pementaan Standar Lulusan, Kompetensi Dasar dan Indikator, penyusunan silabus dan Rencana Pelaksanaan Pembelajaran. Pada komponen tahapan pembelajaran yang tertera dalam RPP, disesuaikan dengan sintak implementasi model pembelajaran Problem Based Learning. Menyiapkan instrumen-instrumen pengumpulan data berupa test prestasi belajar. Menetapkan jadwal pelaksanaan tindakan, koordinasi dengan teman sejawat melalui kegiatan MGMP dalam menentukan guru sebagai observer,

Langkah-langkah model pembelajaran Problem Based Learning adalah; Pembukaan, meliputi; Berdoa bersama, persensi, motivasi, apersepsi, membahas tugas-tugas pada pertemuan sebelumnya, menyampaikan kompetensi dasar yang akan dibahas, tujuan pembelajaran dan indikator ketercapaian KKM. Pada kegiatan kegiatan ini, meliputi:5 tahap yakni; (1) orientasi siswa kepada masalah, (2) mengorganisasikan siswa untuk belajar, (3) membimbing penyelidikan individual maupun kelompok, (4) mengembangkan dan menyajikan hasil karya dan (5) menganalisis dan mengevaluasi proses pemecahan masalah. Penutup meliputi; Bersama-sama siswa membuat resume hasli pembahasan materi, Melaksanakan postest, Memberikan tugas untuk pertemuan berikutnya. Langkah-langkah tersebut secara konsisten dilaksanakan dari pertemuan ke-1 sampai pertemuan ke-3. Bersamaan dengan pelaksanaan tindakan, dilaksanakan juga kegiatan observasi. Kegiatan yang dilaksanakan pada tahap observasi ini adalah; Mencatat semua kegiatan yang terjadi, semua reaksi yang sudah dilakukan, menggunakan lembar observasi/tes prestasi untuk mengumpulkan data, mencek tujuan penelitian, indikator keberhasilan penelitian, efektivitas waktu, kegiatan dan proses pelaksanaan, dan membandingkan hasil yang didapat dengan efektivitas proses. Hasil observasi dapat dilihat pada Tabel 1.

Tabel 1. Hasil Prestasi belajar Bahasa Indonesia dalam memahami isi teks Siklus I

\begin{tabular}{rcc} 
Ko No & Nilai & Keterangan \\
KKM & 75 & \\
Rata-Rata & 75,35 & \\
Jml Siswa Tuntas & 20 & Orang \\
Tdk Tuntas & 17 & Orang \\
\% Ketuntasan & 54,05 & \\
\hline
\end{tabular}

Analisis kuantitatif keterampilan membaca siklus I Rata-rata meningkat dari kondisi awal menjadi 75,95 dengan ketuntasan belajar mencapai 70,27 \%. Keberhasilan yang diperoleh siswa dengan menunjukkan hasil rata-rata; 75,95, ketuntasan belajar; 70,27\%. Dari data tersebut dapat diketahui bahwa jumlah siswa yang sudah tuntas atau hasil rata-rata nilai diatas 75 adalah sebanyak 20 orang dan jumlah siswa yang belum tuntas atau hasil rata-rata nilai kurang dari 75 adalah sebanyak 17 orang. Terhadap siswa yang belum tuntas dibina kemabali dengan memberikan pembelajaran remedial. Berdasarkan rata-rata nilai keterampilan berbicara pada akhir siklus I terjadi peningkatan presstasi belajar sebanyak 4,24 yakni dari rata-rata keterampilan awal 71,11 ke siklus I rata-rata keterampilan menjadi 75,95. Peningkatan ini benar-benar merupakan pengaruh dari implementasi model pembelajaran 
Problem Based Learning, yang telah direncanakan secara matang, dilaksanakan sesuai tahapannya, dan diobservasi dengan mengacu pada instrumen yang sudah disiapkan. Perencanaan yang dimulai dengan menyusun RPP yang baik dan benar sesuai alur model pembelajaran Problem Based Learning.

Keunggulan penelitian ini adalah menuntun siswa mampu meningkatkan kemampuan belajarnya. Pada saat pelaksanaan, peneliti telah mengupayakan agar alur model pembelajaran Problem Based Learning berjalan sesuai harapan sehingga siswa betul belajar sesuai harapan model pembelajaran ini.

Kendala yang masih ada adalah hasil belum mencapai indikator keberhasilan penelitian. Hal ini karena pola pembelajaran siswa baru mulai diupayakan belajar menggunakan model pembelajaran yang menuntut siswa dapat menemukan sendiri, sedangkan model pembelajaran yang lama masih sifatnya menyuapi. Karena model ini baru mulai dicobakan, para siswa masih tercengang memikirkan kebiasaan yang lama dimana mereka masih senang untuk disuapi. Pengamatan/observasi juga sudah berjalan sesuai harapan walaupun hasilnya belum memenuhi kriteria usulan penelitian mengingat peneliti baru mulai menggunakan model pembelajaran yang baru, dimana guru terkendala dalam merubah kebiasaan untuk tidak menyuap lagi atau tidak menceramahkan materi, sedang dipihak siswa sering masih menunggu agar disuapi.

Seperti halnya penyajian hasil penelitian siklus I, pada siklus II ini juga dilaksanakan melalui tahapan-tahapan perencanaan, pelaksanaan, observasi dan refleksi. Lebih rinci penyajian hasil penelitian siklus II. Dengan melihat semua hasil yang didapat pada siklus I, baik refleksi data kualitatif maupun refleksi data kuantitatif, maka untuk perencanaan pelaksanaan penelitian di siklus II, Seperti pelaksanaan siklus sebelumnya, pelaksanaan siklus II ini Langkah-langkah model pembelajaran Problem Based Learning sama seperti siklus sebelumnya. Hasil observasi siklus II disajikan pada Tabel 2.

Tabel 2. Prestasi Belajar Bahasa Indonesia dalam memahami isi teks Siklus II

\begin{tabular}{|c|c|c|c|}
\hline No & Komponen & Nilai & Keterangan \\
\hline & KKM & 75 & \\
\hline & Rata-Rata & 79,19 & \\
\hline & Jml Siswa Tuntas & 33 & Orang \\
\hline & Tdk Tuntas & 4 & Orang \\
\hline & $\%$ Ketuntasan & 89,19 & \\
\hline
\end{tabular}

Sumber : Hasil pengolahan data 2016

Analisis Kuantitatif siklus II, rata-rata sudah mencapai 79,15 dan ketuntasan belajar klasikal telah mencapai 89,19 \% . Dari hasil penelitian dtemukan bahwa nilai rata-rata yang diperoleh pada siklus II menunjukkan peningkatan sebanyak 3,84 dari siklus I yaitu 75,95 menjadi 79,19 pada siklus II, ketuntasan belajar yang diperoleh pada siklus II juga menunjukkan peningkatan sebanyak 35,14 dari siklus I yaitu 54,05\% menjadi 89,19 \% pada siklus II. Mengacu kepada data ini ditemukan 33 siswa dengan nilai rata-rata melebihi KKM (75), dan masih ada sebanyak 4 siswa yang mendapat nilai di bawah KKM (75). Siswa yang memperoleh nilai di bawah KKM akhirnya dibina kembali, diberi arahan-arahan, motivasi-motivasi, penguatan-penguatan agar mereka berupaya lebih baik. Secara keseluruhan hasil yang didapat telah memenuhi kriteria keberhasilan penelitian sehingga tidak diterikan lagi ke siklus berikutnya. Sebagai dasar mengetahui perkembangan hasil penelitian ini maka berikut ini disajikan rekapitulasi hasil sesuai dengan Tabel 3.

Tabel 3. Rekapitulasi perkembangan nilai memahami isi teks

\begin{tabular}{cccc}
\hline Aspek & Awal & Siklus I & Siklus II \\
Rata-Rata & 71,11 & 75,35 & 79,19 \\
Ketuntasan & 29,73 & 54,05 & 89,19 \\
\hline
\end{tabular}

Selanjutnya rekap hasil penelitian tersebut jika disajikan dengan grafik maka akan terlihat seperti gambar berikut; 


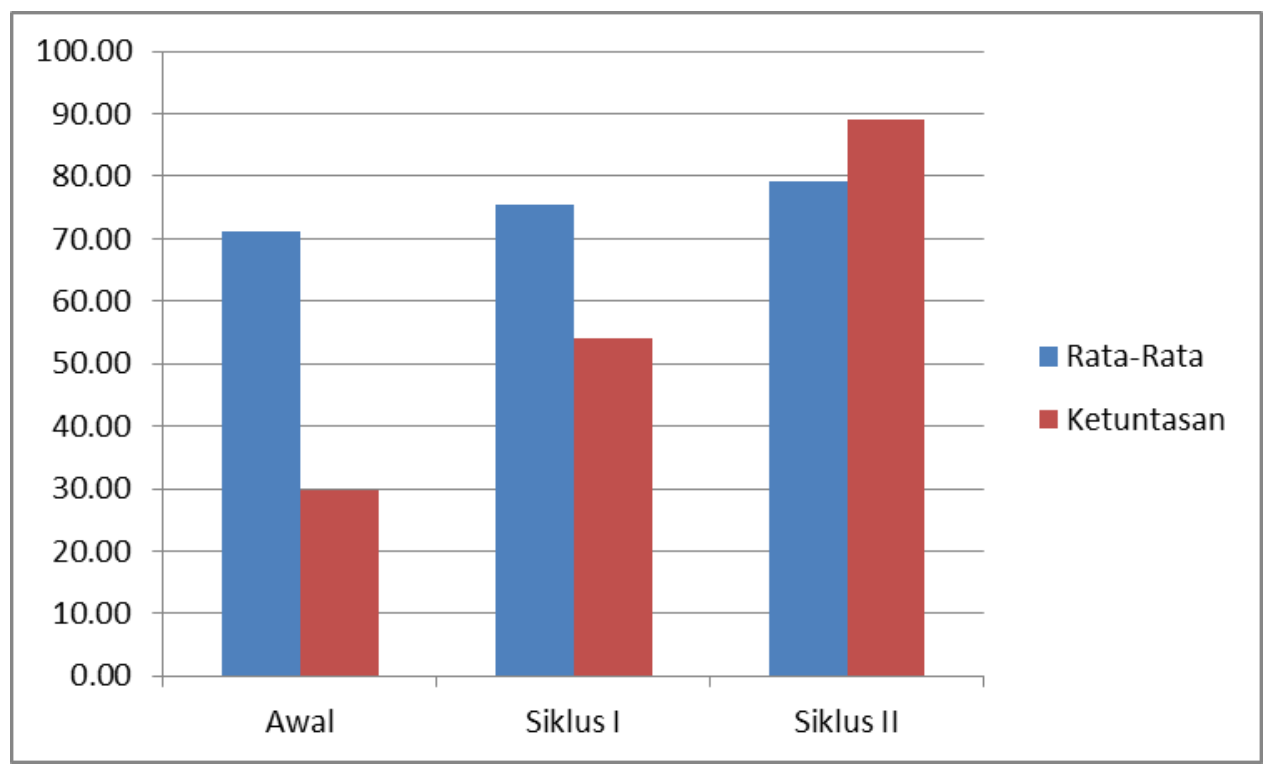

Gambar 1. Grafik Perkembangan hasil penelitian

\section{Pembahasan}

Pembahasan hasil yang diperoleh dari Siklus I, dalam perencanaan, pelaksanaan dan observasi siklus I adalah; hasil penilaian keterampilan memahami isi bacaan membuat siswa untuk betul-betul untuk menyiapkan diri sebaik-baiknya. Hasil ini menunjukkan peningkatan apabila dibandingkan dengan nilai awal siswa sesuai data yang sudah disampaikan dalam analisis sebelumnya. Hasil tes di siklus I telah menemukan efek utama bahwa penggunaan metode tertentu akan berpengaruh terhadap prestasi belajar siswa yang dalam hal ini adalah model pembelajaran Problem Based Learning. Hal ini sesuai dengan hasil meta analisis metode pembelajaran yang dilakukan oleh Soedomo (1989/1990) yang menyatakan bahwa metode pembelajaran yang diterapkan oleh seorang guru berpengaruh terhadap prestasi belajarnya.

Seperti telah diketahui bersama bahwasannya mata pelajaran Bahasa Indonesia menitikberatkan pembelajaran pada aspek kemampuan memahami suatu bacaan/teks sebagai pedoman pembelajaran sehari-hari. Untuk penyelesaian kesulitan yang ada maka penggunaan metode ini dapat membantu siswa untuk berkreasi, bertindak aktif, bertukar pikiran, mengeluarkan pendapat, bertanya, berdiskusi, berargumentasi, bertukar informasi dan memecahkan masalah yang ada bersama dengan anggota kelompok diskusinya. Hal inilah yang membuat siswa berpikir lebih tajam, lebih kreatif dan kritis sehingga mampu untuk memecahkan masalah-masalah yang kompleks dan efek selanjutnya adalah para siswa akan dapat menguasai kompetensi berbicara lebih jauh.

Kendala yang masih tersisa yang perlu dibahas adalah memahami isi bacaan yang dicapai pada siklus I ini belum memenuhi harapan sesuai dengan kriteria keberhasilan penelitian yang diusulkan pada mata pelajaran Bahasa Indonesia di sekolah ini yaitu 75. Oleh karenanya upaya perbaikan lebih lanjut masih perlu diupayakan sehingga perlu dilakukan perencanaan yang lebih matang untuk siklus selanjutnya.

Pembahasan Hasil yang Diperoleh dari Siklus II, Hasil yang diperoleh dari hasil penilaian keterampilan memahami isi bacaan di siklus II menunjukkan rata-rata nilai siswa telah berhasil meningkat. Strategi pembelajaran Problem Based Learning merupakan model yang cocok bagi siswa apabila guru menginginkan mereka memiliki kemampuan berkreasi, berargumentasi, mengeluarkan pendapat secara lugas, bertukar pikiran, berargumentasi, mengingat penggunaan metode ini adalah selain bertujuan untuk memupuk kemampuan berbicara dihadapan orang banyak juga mempersiapkan siswa untuk selalu memiliki pengetahuan dan keterampilan yang maksimal.

Hasil penelitian ini ternyata telah memberi efek utama bahwa model yang diterapkan dalam proses pembelajaran berpengaruh secara signifikan terhadap prestasi belajar siswa. Temuan ini membuktikan bahwa guru sudah tepat memilih metode dalam melaksanakan proses pembelajaran karena pemilihan metode merupakan hal yang tidak boleh dikesampingkan. Hal ini sejalan pula dengan temuan-temuan peneliti lain seperti yang dilakukan oleh Budiastana (2006) dan Santi (2012) yang pada dasarnya menyatakan bahwa strategi pembelajaran Problem Based Learning yang diterapkan berpengaruh terhadap prestasi belajar siswa.

Mata pelajaran Bahasa Indonesia menitikberatkan kajiannya pada aspek keterampilan memahami isi bacaan. Untuk memaksimalkan hasil proses pembelajaran, strategi pembelajaran Problem Based 
Learning menempati tempat yang penting karena dapat mengaktifkan siswa secara maksimal. Dari nilai yang diperoleh siswa, lebih setengah siswa mendapat nilai diatas KKM. Dari perbandingan nilai ini sudah dapat diyakini bahwa keterampilan memahami isi bacaan dapat ditingkatkan dengan penggunaan strategi pembelajaran Problem Based Learning. Walaupun penelitian ini sudah bisa dikatakan berhasil, namun pada saat-saat peneliti mengajar di kelas cara selanjutnya, cara ini akan terus dicobakan termasuk di kelas-kelas lain yang peneliti komponen-komponen lainnya seperti bahan ajar.

Setelah dibandingkan nilai awal, nilai siklus I dan nilai siklus II, terjadi kenaikan yang signifikan dan kenaikan ini tidak bisa dipandang sebelah mata karena kenaikan nilai ini adalah dari upaya-upaya yang maksimal yang dilaksanakan peneliti demi peningkatan mutu pendidikan dan kemajuan pendidikan khususnya di SMP Negeri 2 Singaraja.

Penyelesaian kesulitan yang ada penggunaan metode ini dapat membantu siswa untuk berkreasi, bertukar pikiran, mengeluarkan pendapat, bertanya, berargumentasi, bertukar informasi dan memecahkan masalah yang ada. Hal inilah yang membuat siswa berpikir lebih tajam, lebih kreatif dan kritis sehingga mampu untuk memecahkan masalah-masalah yang kompleks dan efek selanjutnya adalah para siswa akan dapat memahami isi teks lebih jauh. Hasil yang dicapai pada siklus I ini belum memenuhi harapan sesuai dengan kriteria keberhasilan penelitian yang diusulkan pada mata pelajaran Bahasa Indonesia di sekolah ini yaitu mencapai 85\%. Oleh karenanya upaya perbaikan lebih lanjut masih perlu diupayakan sehingga perlu dilakukan perencanaan, pelaksanaan, observasi dan refleksi yang lebih berkualitas.

Temuan ini membuktikan bahwa guru sudah tepat memilih metode dalam melaksanakan proses pembelajaran karena pemilihan metode merupakan hal yang tidak boleh dikesampingkan. Hal ini sejalan pula dengan temuan-temuan peneliti lain seperti yang dilakukan oleh Inten (2004) dan Puger (2004) yang pada dasarnya menyatakan bahwa metode pembelajaran yang diterapkan berpengaruh terhadap prestasi belajar siswa. Model pembelajaran Problem Based Learning menempati tempat yang penting karena dapat mengaktifkan siswa secara maksimal. Dari nilai yang diperoleh, siswa memperoleh nilai di atas KKM. Dari nilai ini sudah dapat diyakini bahwa prestasi belajar dalam memahami isi teks siswa dapat ditingkatkan melalui model pembelajaran Problem Based Learning. Setelah dibandingkan nilai awal, nilai siklus I dan nilai siklus II, terjadi kenaikan. Dalam hasil penelitian dari I Wayan Sadia (2008), menurut persepsi guru model pembelajaran yang dipandang dapat memberi kontribusi dalam mengembangkan keterampilan berpikir kritis adalah pembelajaran kontekstual, model pembelajaran berbasis masalah (PBL), model problem solving, model sains-teknologi masyarakat, model siklus belajar dan model pembelajaran berbasis penilaian portofolio. Kenneth J. Oja (2011), menyatakan bahwa terdapat hubungan positif antara penerapan PBL terhadap keterampilan berpikir kritis siswa keperawatan. Tetapi perlu diperketat dalam penggunaan PBL untuk mengevaluasi berpikir kritis. Penelitian sebelumnya oleh Mohamad (2011) menunjukkan bahwa evaluasi diri dalam pembelajaran PBL dapat meningkatkan kinerja diri. Tahir (2011) menunjukkan bahwa model PBL dapat meningkatkan infrastruktur pendidikan denganmengkaji tempat dan ruang belajar dalam pendidikan teknik. Nalliveettil (2013) menemukan bahwa audiovisual dapat menghemat waktu dan tenaga kerja daritenaga pengajar. Eliyana (2014) menyatakan bahwa model pembelajaran PBLdapat meningkatkan hasil belajar siswa pada materi keliling dan luas. Farkhatus (2012) penggunaan media audiovisual meningkatkan proses dan hasil belajar siswa. Agustin (2013) model pembelajaran PBL meningkatkan Aktivitas siswa dan hasil belajar matematika. Utami (2013) menunjukan bahwa penggunaan audiovisual dapat meningkatkan pemahaman konsep siswa di sekolah dasar. Didalam penelitian ini terbukti bahwa model PBL dapat meningkatkan kemampuan memahami teks. Berdasarkan penelitian yang telah dilakukan, terlihat bahwa prestasi belajar dalam memahami teks di siklus II menunjukkan bahwa kemampuan siswa dalam mengikuti pelajaran sudah baik. Ini terbukti dari rata-rata nilai siswa meningkat. Model Pembelajaran Problem Based Learning merupakan model yang cocok bagi siswa apabila guru menginginkan mereka memiliki kecerdasan dalam berargumentasi, mengeluarkan pendapat secara lugas, bertukar pikiran, mengingat penggunaan metode ini adalah untuk mengarahkan dan memotivasi siswa untuk mau lebih giat dalam menempa ilmu.

\section{Simpulan dan Saran}

Berdasar pada semua data yang telah disampaikan, maka dapat disimpulkan bahwa model pembelajaran Problem Based Learning dapat meningkatkan kemampuan siswa kelas IX-4 SMP Negeri 2 Singaraja pada semester ganjil tahun pelajaran 2016/2017 dalam memamahi isi teks. Berdasarkan temuan yang sudah disimpulan, maka disampaikan saran-saran sebagai berikut: Dalam melaksanakan proses pembelajaran pada mata pelajaran Bahasa Indonesia pada kemampuan berbicara, penggunaan model pembelajaran Problem Based Learning semestinya menjadi pilihan dari beberapa metode yang ada mengingat metode ini telah terbukti dapat meningkatkan kerjasama, berkreasi, bertindak aktif, bertukar 
informasi, mengeluarkan pendapat, bertanya, berdiskusi, berargumentasi dan lain-lain. Walaupun penelitian ini sudah dapat membuktikan efek utama dari model pembelajaran Problem Based Learning dalam meningkatkan keterampilan menceritakan kembali isi cerita, sudah pasti masih ada hal-hal yang belum sempurna dilakukan, oleh karenanya kepada peneliti lain yang berminat meneliti topik yang sama untuk meneliti bagian-bagian yang tidak sempat diteliti. Selanjutnya untuk adanya penguatan-penguatan, diharapkan bagi peneliti lain untuk melakukan penelitian lanjutan guna verifikasi data hasil penelitian.

\section{Daftar Rujukan}

Arikunto, S. S. (2006). Penelitian Tindakan Kelas. Jakarta: Bumi Aksara.

Dahar, R. W. (1989). Teori-Teori Belajar. Jakarta: erlangga.

Depdikbud. (1994). Petunjuk Pelaksanaan Proses Belajar-Mengajar. Jakarta: Direktorat Pendidikan Menengah Umum.

Depdiknas. (2011). Membimbing Guru dalam Penelitian Tindakan Kelas. Jakarta: Pusat Pengembangan Tenaga Kependidikan Badan Pengembangan Sumber Daya Manusia Pendidikan Penjaminan Mutu Pendidik.

Dewi, N. P. A. M. dkk. (2013). Pengaruh Model Pembelajaran Problem Based Learning (PBL) Berbantuan Media Video Terhadap Hasil Belajar IPA Kelas IV SD Negeri Pergung. Singaraja: Universitas Pendidikan Ganesha.

Dhamayanti, N. L. D. D. A. dkk. (2014). Pemaknaan Siswa Kelas X Sma Lab Undiksha Singaraja Terhadap Pembelajaran Geografi Dengan PBL Dalam Menumbuhkan Pola Pikir Kritis. Singaraja: Universitas Pendidikan Ganesha.

Juliantari, N. K. (2017). Paradigma Analisis Wacana Dalam Memahami Teks dan Konteks Untuk Meningkatkan Kemampuan Membaca Pemahaman. Acarya Pustaka, 3(1).

Kurniawati, I. L. dan D. M. A. (2013). Pengembangan Bahan Ajar Berbasis Masalah Pada Mata Pelajaran Kimia SMA Kelas X Dalam Materi Hidrokarbon. In Seminar Nasional FMIPA UNDIKSHA III. Singaraja: Universitas Pendidikan Ganesha.

Nafiah, Y. N. (2012). Penerapan Model Problem-Based Learning untuk Meningkatkan Keterampilan Berpikir Kritis dan Hasil Belajar Siswa. Jurnal Pendidikan Vokasi, 1(1).

Natalia. (2017). Penerapan Model Pembelajaran Berbasis Masalah Dengan Bantuan Media Video Untuk Meningkatkan Keterampilan Menulis Teks Eksposisi Siswa. Jurnal Penelitian Dan Pengembangan Pendidikan, 1(2), 75-81.

Popham, W. J. dan E. L. B. (1984). Bagaimana Mengajar Secara Sistematis. yogyakarta: kanisius.

Sibawae. (2017). Peningkatan Kemampuan Penggunaan Ejaan dan Tanda Baca dalam Menulis Teks Laporan Observasi Dengan Metode Jigsaw. Jurnal Penelitian Dan Pengembangan Pendidikan, 1(1).

Sudiatmika, I. M. A. (2016). Pengaruh Penggunaan Multimedia Pada Model Problem Based Learning (PBL) Terhadap Hasil Belajar Kimia Siswa. In Prosiding Seminar Nasional MIPA 2016. Singaraja: Universitas Pendidikan Ganesha.

Swari , Putu Kartika Widya, I. M. A. W. (2015). Penerapan Model Pembelajaran Berbasis Masalah (Problem Based Learning) Berbantuan Jobsheet Untuk Meningkatkan Hasil Belajar Siswa Pada Mata Pelajaran Pemrograman Web di Kelas X TKJ 4 Smk Negeri 3 Singaraja. Kumpulan Artikel Mahasiswa Pendidikan Teknik Informatika (KARMAPATI), 4(3).

Udiyani, I. A. P. (2017). Pengaruh Metode Sugesti Imajinasi dengan Media Foto terhadap Keterampilan Menulis Teks Deskripsi ditinjau dari Minat Menulis Siswa Kelas Vii Smp Negeri 12 Denpasar. Jurnal Ilmiah Pendidikan Dan Pembelajaran, 1(1). 
Wewe, M. (2017). The Effect Of Problem Based Learning Model And Mathematic-Logical Intelligence Toward Mathematics Learning Achievement. Journal of Education Technology, 1(1), 7-17.

Wibawa, I. M. C. (2014). Pengaruh Beberapa Model Pembelajaran Terhadap Pemahaman Konsep IPA Mahasiswa PGSD. In Seminar Nasional FMIPA UNDIKSHA IV. Singaraja: Universitas Pendidikan Ganesha.

Widiana, I. W. (2014). Pengaruh Model Problem Based Learning Berbasis Asesmen Kinerja Terhadap Kemampuan Berpikir Kritis Mahasiswa. In Seminar Nasional Riset Inovatif Ii.

Yanti, N. W. W. (2013). Penerapan Model Pembelajaran Pbl Berbantuan Power Point Untuk Meningkatkan Hasil Belajar Pkn. Singaraja: Universitas Pendidikan Ganesha. 